\title{
Who Owns the Land in Asia? Formal recognition of community-based land rights
}

The question of who owns the world's lands and natural resources is a major source of contestation around the globe, affecting prospects for rural economic development, human rights and dignity, cultural survival, political stability, conservation of the environment, and efforts to combat climate change. To inform advocacy and action on community land rights, RRI has published Who Owns the World's Land? A global baseline of formally recognized indigenous $\mathcal{E}$ community land rights ("the global baseline") ${ }^{1}$ which identifies the amount of land national governments have formally recognized as owned or controlled by Indigenous Peoples and local communities across 64 countries constituting 82 percent of global land area. The report focuses on community-based tenure regimes, which include any system where formal rights to own or manage land or terrestrial resources are held at the community level, including lands held under customary tenure regimes. This brief summarizes findings on community ownership and control of lands in the 15 countries in Asia that were included in the global baseline.

\section{Key Findings}

- Twenty-six percent of land in Asia is owned or controlled by Indigenous Peoples and local communities, compared with 18 percent globally; Asia leads both Latin America and SubSaharan Africa in community-based tenure recognition.

- China dominates the results, contributing 87 percent of land owned or controlled by communities in the region.

- Without China's contribution, Asia falls behind both Latin America and Sub-Saharan Africa. Six percent of land in the remaining 14 Asian countries is controlled by local communities and Indigenous Peoples, and less than half a percent is owned by them.
- In more than half of the Asian countries studied, Indigenous Peoples and local communities own or control less than 1 percent of the country's land area.

\section{Role of Community-Based Tenure in Asia}

Communities in Asia rely on common-property resources to support their livelihoods, agricultural activities, and cultural heritage; however, they frequently lack secure rights to these resources. India serves as an example of the variety and importance of shared resources to communities. A 2001 study estimated that US $\$ 5$ billion (or 12 percent) of poor rural households' annual incomes were based on common-property resources, which include "village pastures, community forests, waste lands, common threshing grounds, waste dumping places, watershed drainages, village ponds, tanks, rivers/rivulets, and riverbeds." ${ }^{2}$ These resources contribute to the incomes of approximately 266 million people. Similarly, an estimated 200 million people across the Asia-Pacific region depend on non-timber forest products for both financial support and 
subsistence needs. ${ }^{3}$ Traditional community-based agricultural practices, such as the shifting methods of agricultural production practiced by the Kmhmu communities of Lao PDR and the Dayak Jalai of West Kalimantan in Indonesia, also play an important role in food security. ${ }^{4}$ Governments frequently restrict such traditional practices in response to population pressures, leaving communities vulnerable to food insecurity.

Formal, legal recognition of community-based tenure can also support conservation and help combat climate change. In Nepal, the government has supported community forestry, leading to improved forest health across 1.6 million hectares (Mha) of forest land. By contrast, carbon emissions due to deforestation are high in Indonesia, where the government recognizes communities' rights to less than 1 Mha of the over 40 Mha of land that communities claim as customary (Adat) lands.

Despite the importance of community and indigenous land rights to livelihoods, culture, food security, and conservation, the global baseline demonstrates that many Asian countries still fail to prioritize community-based tenure. Many governments issue commercial concessions without regard to how they affect communities or to the potential unrest and social conflict that may arise from disputes over land and natural resources.

\section{Asia Results}

The global baseline identifies two broad categories of formal recognition for community-based tenure regimes: community “ownership," where communities have a stronger set of land rights, and community "control," where governments place significant restrictions on communities but do recognize some key rights, such as the right to manage their lands or the right to exclude outsiders.

Globally, Indigenous Peoples and local communities control 8 percent of land and own an additional 10 percent, totaling 18 percent. In Asia, 26 percent of land is either owned or controlled

\begin{tabular}{|c|c|c|c|c|c|c|c|c|}
\hline \multirow[t]{2}{*}{ Country } & \multirow[t]{2}{*}{$\begin{array}{l}\text { Total } \\
\text { Country } \\
\text { Area } \\
\text { (Mha) } \\
\end{array}$} & \multicolumn{2}{|c|}{$\begin{array}{c}\text { Designated } \\
\text { for Indigenous } \\
\text { Peoples and Local } \\
\text { Communities }\end{array}$} & \multicolumn{2}{|c|}{$\begin{array}{l}\text { Owned by } \\
\text { Indigenous } \\
\text { Peoples and Local } \\
\text { Communities } \\
\end{array}$} & \multicolumn{2}{|c|}{$\begin{array}{c}\text { Total Area Designated for } \\
\text { or Owned by Indigenous } \\
\text { Peoples and Local } \\
\text { Communities }\end{array}$} & \multirow[t]{2}{*}{ Income Level } \\
\hline & & Area (Mha) & $\begin{array}{c}\text { Percent } \\
\text { of } \\
\text { Country } \\
\text { Area }\end{array}$ & $\begin{array}{l}\text { Area } \\
\text { (Mha) }\end{array}$ & $\begin{array}{c}\text { Percent } \\
\text { of } \\
\text { Country } \\
\text { Area }\end{array}$ & $\begin{array}{c}\text { Total Area } \\
\text { (Mha) }\end{array}$ & $\begin{array}{c}\text { Total Percent } \\
\text { of Country } \\
\text { Area }\end{array}$ & \\
\hline Cambodia & 17.65 & 0.58 & $3.30 \%$ & 0.01 & $0.04 \%$ & 0.59 & $3.33 \%$ & $\mathrm{~L}$ \\
\hline China & 942.57 & ---- & $0.00 \%$ & 465.70 & $49.41 \%$ & 465.70 & $49.41 \%$ & $M$ \\
\hline India & 297.32 & ----- & $0.00 \%$ & 0.13 & $0.04 \%$ & 0.13 & $0.04 \%$ & M \\
\hline Indonesia & 181.16 & 0.35 & $0.19 \%$ & ----- & $0.00 \%$ & 0.35 & $0.19 \%$ & $M$ \\
\hline Kazakhstan & 269.97 & 21.48 & $7.96 \%$ & ----- & $0.00 \%$ & 21.48 & $7.96 \%$ & M \\
\hline Kyrgyzstan & 19.18 & 7.69 & $40.07 \%$ & ----- & $0.00 \%$ & 7.69 & $40.07 \%$ & $M$ \\
\hline Lao PDR & 23.08 & 0.02 & $0.10 \%$ & ----- & $0.00 \%$ & 0.02 & $0.10 \%$ & $M$ \\
\hline Myanmar & 65.33 & 0.05 & $0.07 \%$ & ---- & $0.00 \%$ & 0.05 & $0.07 \%$ & $M$ \\
\hline Nepal & 14.34 & 1.92 & $13.41 \%$ & $\begin{array}{l}---- \\
\end{array}$ & $0.00 \%$ & 1.92 & $13.41 \%$ & $\mathrm{~L}$ \\
\hline Philippines & 29.82 & 1.65 & $5.55 \%$ & 4.71 & $15.79 \%$ & 6.36 & $21.34 \%$ & $M$ \\
\hline Tajikistan & 14.00 & No data & $0.00 \%$ & ---- & $0.00 \%$ & 0.00 & $0.00 \%$ & M \\
\hline Thailand & 51.09 & 0.48 & $0.94 \%$ & ---- & $0.00 \%$ & 0.48 & $0.94 \%$ & $\mathrm{M}$ \\
\hline Timor-Leste & 1.49 & ----- & $0.00 \%$ & ---- & $0.00 \%$ & 0.00 & $0.00 \%$ & $M$ \\
\hline Turkmenistan & 46.99 & 30.29 & $64.46 \%$ & ---- & $0.00 \%$ & 30.29 & $64.46 \%$ & $M$ \\
\hline Uzbekistan & 42.54 & |---- & $0.00 \%$ & |---- & $0.00 \%$ & 0.00 & $0.00 \%$ & $M$ \\
\hline Regional Total & 2016.41 & 64.52 & $3.20 \%$ & 470.54 & $23.34 \%$ & 535.06 & $26.54 \%$ & \\
\hline Global Total & 10672.70 & 854.90 & $8.01 \%$ & 1084.71 & $10.16 \%$ & 1939.62 & $18.17 \%$ & \\
\hline
\end{tabular}


by Indigenous Peoples and local communities. Compared to the global results, less land is designated for Indigenous Peoples and local communities (3 percent), while a significantly higher proportion of land is owned by them (23 percent). The countries studied are almost exclusively middle-income countries, with Cambodia and Nepal being the only low-income countries in the sample.

China drives the results for the whole region. If China is excluded, the area of land owned by Indigenous Peoples and local communities in the remaining 14 countries drops drastically to only 0.45 percent, while the area controlled by them rises to 6 percent (see below). In more than half of the countries studied, Indigenous Peoples and local communities own or control less than 1 percent of the country's land area, including both agricultural and forested lands.

In addition to China, three other Asian countries recognize Indigenous Peoples' and local communities' rights to own or control land to a greater degree than the global average.

Turkmenistan and Kyrgyzstan designate 64 percent and 40 percent of their land, respectively, for community control, and the Philippines designates 21 percent of its land for community ownership or control. Similar to China, Turkmenistan and Kyrgyzstan have experienced a history of socialism which influences their current pasture management policies. In these systems, either municipal or state lands are designated for grazing use, with local communities or Pasture Associations having some common access and management rights to these lands. In practice, however, it is difficult to ascertain the extent to which local communities and Pasture Associations actually access these pastures due to a lack of publicly available disaggregated data.
While many Asian countries lag behind in formally recognizing Indigenous Peoples' and local communities' rights to specific lands, the majority of countries have enacted laws that would allow them to recognize at least some community-based land rights. Thirteen of the 15 Asian countries studied have statutory mechanisms in place for recognizing local communities' and Indigenous Peoples' rights to control and manage land to varying degrees. However, 11 of these countries only recognize their rights to control land, failing to establish the legal foundations for community-based ownership. Two Asian countries (Cambodia and the Philippines) provide for both community-based ownership and control, and two Asian countries (China and India ${ }^{5}$ ) only recognize community ownership. No statutory tenure regimes recognizing community control or ownership exist in Timor-Leste ${ }^{6}$ or Uzbekistan.

\section{Significance of the China Data}

China constitutes 43 percent of the land in Asia included in the study and contributes 87 percent of the total area owned or controlled by communities in the region. China recognizes 49 percent of its land area as owned by Indigenous Peoples and local communities in the form of collective ownership of forest land and pastures.

In contrast with the situation in many countries, where community-based tenure regimes have been enacted in response to "bottom up" pressure to formally recognize customary tenure or local management systems, collectives in China were formed by statute in the 1950 s by the communist regime. Some of these lands were functionally privatized during a period of "decollectivization" that began in 1978, but many rural communities continue to hold rights to grasslands and forests at the community level. In these areas, governance of the land remains collective, although many decisions are also made at the household level. For example, summer pastures are used collectively by administrative villages, while winter pastures are used exclusively by smaller "natural villages." Individual households obtain contracts for long-term use rights that vary across China's diverse regions. Forests in China are managed through a mix of long-term household private use rights and community-based rights that also vary regionally. 


\section{Challenges to Community-Based Tenure in Asia}

Existing laws establishing community-based tenure regimes require further implementation to close the gap between the lands that Indigenous Peoples and local communities hold in practice and the lands to which they have formal legal recognition. For example, India has an enormous opportunity to grant community forest rights under the 2006 Forest Rights Act, which remains largely unimplemented. If fully implemented, the Forest Rights Act would recognize at least 40 Mha of forest land as Community Forests or Community Forest

Resources-benefitting at least 150 million people and marking a momentous shift toward community-based forest governance. Nevertheless, although more than half of India's forests fulfill the requirements set out for Community Forest Resources recognition in the Forest Rights Act, only 1.2 percent of this area has been recognized thus far.

Similarly, in May 2013, an Indonesian Constitutional Court ruled in favor of Indigenous Peoples' right to own customary forest land. Five thousand hectares of Adat (or customary) land have been recognized. However, this area is still vastly smaller than the 40 Mha estimated by the Indigenous Peoples' Alliance of the Archipelago to be held under customary tenure regimes. The court's decision has the potential to increase the percentage of land owned or controlled by Indigenous Peoples from 0.25 percent to approximately 23 percent of Indonesia's total land area, including almost 40 percent of the country's forest land.

Governments' failure to recognize local communities' and Indigenous Peoples' land rights is frequently associated with efforts to promote commercial investment and exports. As of 2014, the government of Indonesia had issued commercial concessions over approximately 30 percent of its land area, many of them overlapping with community lands. ${ }^{7}$ For example, in part of West Kalimantan, oil palm concessions overlap with 59 percent of community forests held under customary tenure regimes. ${ }^{8}$ Granting concessions with little regard for existing community use and customary claims is common across the region, including in Cambodia, where estimates indicate that 22 percent of the country is under concessions or held by local elites, and Myanmar, where oil palm concessions have been issued over approximately 18 percent of the Tanintharyi Region. ${ }^{9}$ In India, the environment ministry has issued guidelines that would allow the private sector to obtain forestry concessions over 40 percent of the country's forests, only 10 to 15 percent of which would be accessible by tribal communities. ${ }^{10}$ Such an effort to privatize India's forests at the expense of communities' rights would be a violation of the 2006 Forest Rights Act.

Heightened pressures from competing land interests by the private sector and other stakeholders generate disputes and social conflict. Of the 270 ongoing land disputes recorded across Cambodia in 2014, almost a third were related to the granting of Economic Land Concessions, which affect almost 80,000 people. ${ }^{11}$

Similarly, in India, 252 land-related conflicts between 2013 and 2014 affected almost one quarter of the districts. ${ }^{12}$

\section{Opportunities for Reform and Way Forward}

While implementation has been slow, the potential for legal recognition of communities' rights to up to 40 Mha of land in both India and Indonesia demonstrates the vast potential for community-based tenure recognition in Asia. Other Asian countries are also currently considering legislation and policies that would strengthen the foundations for community-based tenure recognition. Kazakhstan and Turkmenistan have developed draft pasture codes that would expand community-based pasture rights if adopted. Additionally, land reforms in Timor-Leste and Myanmar are taking shape.

Despite these indications of modest progress, great effort is still needed to secure rights and move towards tenure security.

- Because so many communities across Asia rely on community-based natural resources, community-based tenure recognition is essential not only to economic development, but also to livelihoods, community cohesion, social stability, and conservation.

- The area of land formally recognized under statutory law is much less than the area to which Indigenous Peoples and local communities hold customary rights.

- Formal legal recognition of indigenous and community lands is an important first step, but without effective implementation it is not sufficient to guarantee tenure security. Tenure security requires that states and other actors respect, support, and enforce legal protections in a coherent manner that ensures that commercial concessions and other land uses do not interfere with communities' land rights. 
The global baseline elucidates the current state of community-based tenure recognition and highlights what still needs to be done to help Indigenous Peoples and local communities realize their tenure rights. Now it is up to national governments, communities, civil society, policy advocates, bilateral and multilateral development partners, international organizations, private sector investors, and other stakeholders to leverage this data to advance community-based tenure through lobbying, legislation, regulation, administrative and institutional capacity building, and on-the-ground implementation. The stakes are high, because ultimately community-based tenure security will determine whether Indigenous Peoples and local communities have the legal right to manage their lands as they choose-a question that strikes at the heart of rural peoples' daily lives and has major implications for controlling climate change, ensuring food security, reducing political conflict, and protecting the world's remaining natural resources. 


\section{Endnotes}

${ }^{1}$ This brief was prepared by Chloe Ginsburg and Ilona Coyle based on the full report: Rights and Resources Initiative. 2015. Who Owns the World's Land? A global baseline of formally recognized indigenous and community land rights. Washington, DC: RRI. Available at: http://www.rightsandresources.org/publication/whoownstheland.

\begin{abstract}
${ }^{2}$ Notably, the Global Baseline study only includes terrestrial ecosystems, so all these resources would not be captured within the analytical framework, even if all common resources were formally recognized at the national level, which they are not. Beck, Tony and Cathy Nesmith. 2001. Building on poor people's capacities: the case of common property resources in India and West Africa. World Development 29:1. 119-133, 119 and 121. http://www.rmportal.net/ framelib/cpr-in-india-and-west-africa.pdf, quoting Jodha, N. S. (1986). Common property resources and rural poor in dry regions of India. Economic and Political Weekly, 31(27), 1169-1181.
\end{abstract}

${ }^{3}$ FAO. 2009. State of the World's Forests 2009. Rome: Food and Agriculture Organization of the United Nations. As cited in FAO. 2010. Forest and Climate Change in the Asia-Pacific Region. Forests and Climate Change Working Paper 7. 3. Rome: FAO. http://www.fao.org/docrep/013/i1759e/i1759e00.pdf.

${ }^{4}$ Asia Indigenous Peoples Pact, Food and Agriculture Organization of the United Nations, and International Work Group for Indigenous Affairs. 2015. Shifting Cultivation, Livelihood, and Food Security: New and Old Challenges for Indigenous Peoples in Asia, edited by Christian Erni. Bangkok: FAO, IWGIA, and AIPP. http://www.fao.org/3/a-i4580e.pdf.

${ }^{5}$ There are also several tenure regimes in India that provide communities with such limited rights that they do not meet the RRI definition of lands controlled by Indigenous Peoples and local communities. India also has several subnational tenure regimes at the state level which do not fall within the scope of this study.

${ }^{6}$ Due to the complex and overlapping nature of the Timorese statutory framework, it is not possible to determine the extent to which communities hold formally recognized, statutory rights to land and natural resources at this time.
${ }^{7}$ Alforte, Andrea, Joseph Angan, Jack Dentith, Karl Domondon, Lou Munden, Sophia Murday, and Leonardo Pradela. 2014. Communities as Counterparties: Preliminary Review of Concessions and Conflict in Emerging and Frontier Market Concessions. London: TMP Systems. http://www.rightsandresources. org/wp-content/uploads/Communities-as-Counterparties-FINAL_Oct-211.pdf.

${ }^{8}$ Stevens, Caleb, Robert Winterbottom, Jenny Springer, and Katie Raytar. 2014. Securing Rights, Combating Climate Change. Washington, DC: World Resources Institute and Rights and Resources Initiative. http://www. rightsandresources.org/publication/securing-rights-combating-climate-changehow-strengthening-community-forest-rights-mitigates-climate-change/.

${ }^{9}$ Colchester, Marcus and Sophie Chao. 2013. Updates on agribusiness and large-scale land acquisitions in Southeast Asia: Brief \#1 of 8: Regional Overview. In Agribusiness large-scale land acquisitions and human rights in Southeast Asia. 1-18. Moreton-in-Marsh, England: Forest Peoples Programme. http://www.forestpeoples.org/sites/fpp/files/publication/2013/08/1sla-studies. pdf; Woods, K. 2015. Commercial agriculture expansion in Myanmar: Links to deforestation, conversion timber, and land conflicts. Washington, DC: Forest Trends. http://forest-trends.org/releases/uploads/Conversion_Timber_in_ Myanmar.pdf.

${ }^{10}$ Sambhav Shrivastava, Kumar. 2015. Govt to allow pvt sector to manage $40 \%$ of forests. Hindustan Times, September 13. New Dehli. http://www. hindustantimes.com/india/govt-to-allow-pvt-sector-to-manage-40-of-forests/ story-yOiG4TO4kA2kvykxXNTEBK.html.

${ }^{11}$ The NGO Forum on Cambodia. 2015. Statistical Analysis of Land Disputes in Cambodia, 2014. Phnom Penh: The NGO Forum on Cambodia. http:// www.ngoforum.org.kh/administrator/components/com_ngoforum/files/00ad 824b8515dd9cf8e898bb13f980e5-Layout-Land-dispute-report-2014-Eng.pdf.

${ }^{12}$ Rights and Resources Initiative. 2014. As Modi Government in India Proceeds with Economic Development Agenda, New Map Tracking Land Disputes Shows Disturbing Pattern of Conflicts with Local People. November 25. Washington, DC: RRI. http://www.rightsandresources.org/news/ as-modi-government-in-india-proceeds-with-economic-development-agenda-newmap-tracking-land-disputes-shows-disturbing-rise-in-conflicts-with-local-people/.

For more information on methodology and findings of the full report, please see: http://www.rightsandresources.org/publication/ whoownstheland. To preserve the brevity of this summary, citations have been omitted unless they provide new information not discussed in the full report. 
RRI is a global coalition of 13 Partners and over 150 international, regional, and community organizations advancing forest tenure, policy, and market reforms. RRI leverages the strategic collaboration and investment of its Partners and Collaborators around the world by working together on research, advocacy, and convening strategic actors to catalyze change on the ground.

RRI is coordinated by the Rights and Resources Group, a non-profit organization based in Washington, D.C. For more information, please visit www.rightsandresources.org.

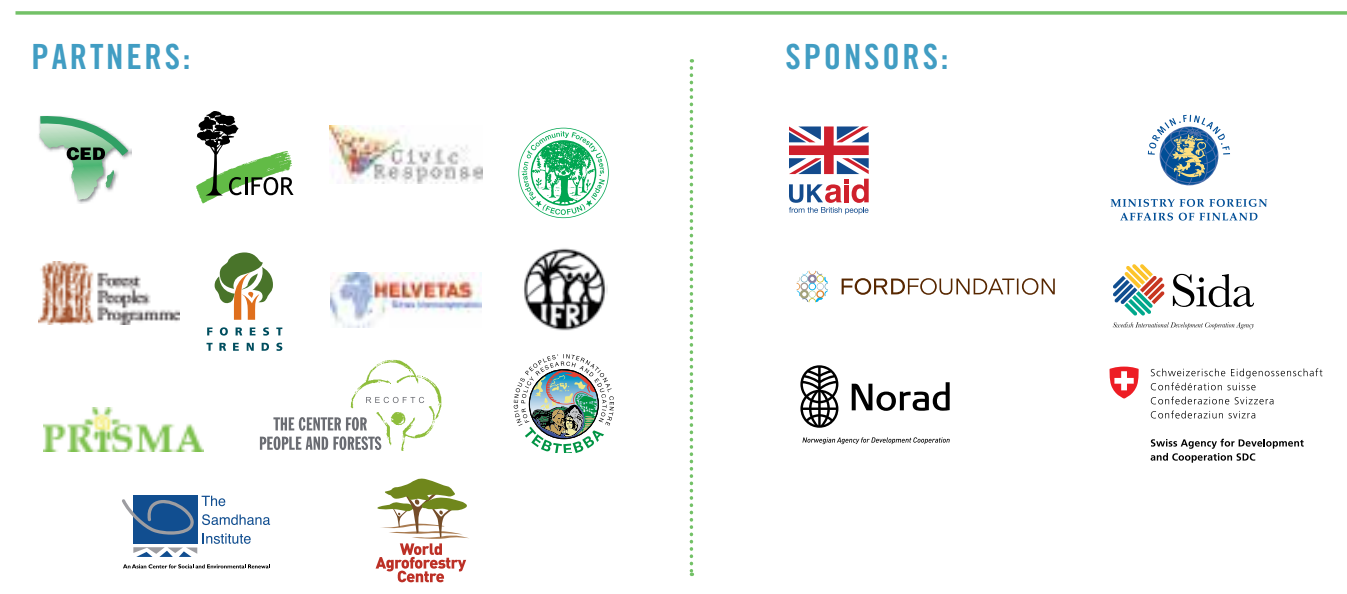

The views presented here are those of the authors and are not necessarily shared by the agencies that have generously supported this work, or all of the Partners of the Coalition.

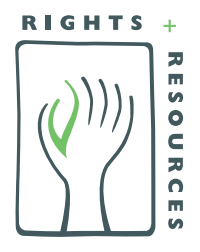

1238 Wisconsin Avenue NW Suite 300

Washington, DC 20007

www.rightsandresources.org 